
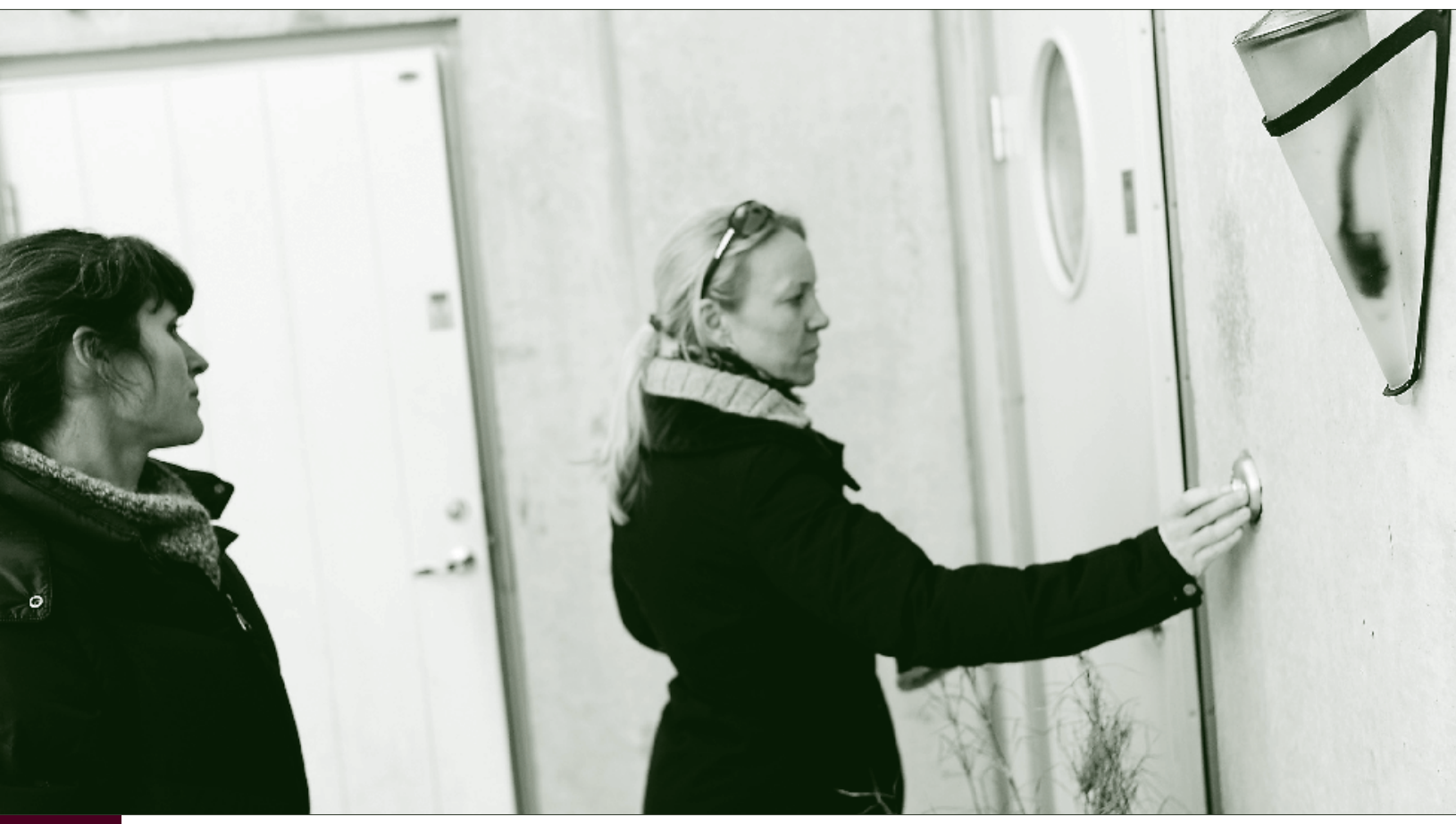

Studiens bakgrunn: Stortinget har vedtatt at alle landets distriktspsykiatriske sentre (DPS) innen 2008 skal opprette ambulante akutteam for personer over 18 år. Teamene skal bidra til økt tilgjengelighet, rask hjelp og økt brukerinvolvering i tjenestetilbudet.

Hensikt: $\AA$ kartlegge antallet etablerte ambulante akutteam i Norge i januar 2010, samt de mest sentrale arbeidsmåtene i teamene.
Metode: Materialet ble samlet inn gjennom en telefonkartlegging til alle landets distriktspsykiatriske sentre i januar 2010.

Resultater: 51 av landets distriktspsykiatriske sentre har team ( $n=76)$. Av de 25 som ikke har vil seks etablere team i løpet av 2010. Det er stor grad av variasjon i tjenestetilbud og arbeidsmåter. De fleste teamene har åpningstid bare på dagtid med noen utvidelser på kvelder og i helger. De fleste team disponerer krisesenger, samarbeider aktivt med pårørende, drar hjem til brukere og tar direkte imot henvendelser.

Konklusjon: De helsepolitiske målsettingene som er vedtatt i relasjon til opprettelsen av ambulante akutteam er bare delvis innfridd. En tredjedel av landets DPS'er har ennå ikke etablert slike team. For å realisere de helsepolitiske og faglig målsettingene kan en faglig veileder for «best practice» utredes, utprøves og evalueres.
Crisis Resolution Home Treatment Teams in Community Mental Health Centres - a survey.

Background: A government resolution in 2008 set a target for all community mental health centres to implement crisis resolution home treatment teams for the adult population. The objective of the teams were to provide availability and access, improved quality and better use of resources and expanded user involvement in mental health crisis services.

Objective: A survey over the establishment of Crisis Resolution Home Treatment Teams in Norway in
January 2010, and some of the central practices in the teams.

Methods: The material collected from all community mental health centres in Norway in January 2010 through a telephone survey.

Results: Fifty-one of the community mental health centres in Norway have implemented teams (n:76). Out of the 25 centres without teams established, 6 plan to do so in 2010. There is comprehensive variation in service organization and clinical practice. Most teams offer services only during the daytime with some extension to afternoons and weekends. Most teams have crisis beds, emphasize collaboration with family members, meet patients at home and accept referrals directly (without referrals from GP).

Conclusion: It is questionable to which extent the health-political target of introducing crisis resolution home treatment teams is fulfilled. Still, $25 \%$ of the Community Mental Health Centres have not established the teams. Best practice guidelines for crisis resolution home treatment teams are strongly recommended for implementation and evaluation.

Key words: mental health care, crisis resolution teams, home treatment, mental health crisis, survey. 


\section{Ambulante akutteam ved distriktspsykiatriske sentre}

Forfattere Bengt Karlsson, Marit Borg og Hege Sjølie

\author{
NØKKELORD \\ - Psykisk helse \\ - Psykisk lidelse \\ - Krise \\ - Kartlegging
}

\section{BAKGRUNN}

I de senere år har modeller for ambulante tjenester blitt etablert i psykisk helsevern, der hensikten er å tilby lokalbasert hjelp i folks nærmiljø. Dette gjelder krisehåndtering, rehabilitering og langtidsoppfølging $(1,2)$. Ambulante akutteam er et slikt tilbud. Stortinget har vedtatt at alle landets distriktspsykiatriske sentre skal opprette slike team innen utgangen av 2008 (3,4). Teamenes primære målgruppe er voksne personer over 18 år som opplever en akutt psykisk krise og ber om hjelp fra teamet. Det kan være mennesker i akutte kriser som opplever suicidalitet, psykisk smerte og kaos samt familieog sosiale problemer. Teamene skal skape et mer helhetlig og tilgjengelig behandlingstilbud som ivaretar pasienters opplevelse av integritet og selvfølelse (3). Nye samarbeidsformer skal utvikles i pasienters lokalmiljø med særlig vekt på en kontekstuell forståelse av psykisk krise og hjemmebehandling. For utdypende lesning om arbeidsformer i ambulante akutteam, se $(5,6)$. Opptrappingsplanen for psykisk helse (7) ble vedtatt av et enstemmig Storting og gjaldt for perioden 1998 til 2009. Opptrappingsplanen innebar en sterk økning av offentlige bevilgninger til psykiske helsetjenester. Like viktig var politikernes påpekning av å utvikle humane tjenester både i form og innhold. Stortinget vedtok et syn på mennesket og psykisk helse som skal være styrende for all virksomhet i arbeidet med psykisk helse. Det skulle legges til grunn et helhetlig menneskesyn hvor alle sider spiller inn inkludert personens psykiske helse. Det er en person i kontekst som erfarer psykisk uhelse, og det viser seg på flere områder enn bare det biologiske eller det sosiale.

Artikkelforfatterne arbeider i forskningsprosjektet «Krisehåndtering og hjemmebe- handling i lokalbasert psykisk helsearbeid». Prosjektets hovedmål er å utforske forståelser og arbeidsmetoder $i$ et nyetablert team, samt pasienterfaringer med psykisk krise og med teamets tjenester (5). Gjennom tre delstudier utvikles forskningsbasert kunnskap om kriseerfaringer, kriseintervensjon og hjemmebehandling. Kravene til kvalitet i psykisk helsetjenester har nødvendiggjort behovet for utvikling av flere og bedre tilpassede forskningsbaserte evalueringsstudier $(8,9)$. Særlig pekes det på behovet for å måle effekten av nye modeller

Hva tilfører denne artikkelen?

Studien viser at det er betydelige forskjeller på hvorvidt distriktspsykiatriske sentre i Norge, i tråd med Stortingets vedtak, har etablert ambulante akutteam for personer over 18 år.

\section{Mer om forfatterne}

Bengt Karlsson er psykiatrisk sykepleier, dr. polit H. Professor, Marit Borg er ergoterapeut, PhD og professor. Hege Sjølie er cand. polit. Alle er ansatt ved $\mathrm{H} \varnothing$ gskolen i Buskerud, avdeling for helsefag. Kontakt: bengt.karlssonahibu.no 
for akutte tjenester, med vekt på bedre behandling av psykiske kriser $(1,2)$. Det var ingen faglig høring eller gjennomførte prosesser med kunnskapsstatus, forut for beslutningen i 2005 om å etablere ambulante akutteam ved alle landets distriktspsykiatriske sentre innen 2008 $(1,2)$. I helsepolitiske føringer ringen av ambulante akutteam i Norge og sentrale elementer i deres faglige profiler og arbeidsmåter.

\section{METODE \\ Materiale}

Materialet består av systematisk innhentet informasjon om ambulante akutteam som er eta-

\section{Krisesenger representerer forskjellige former for tilbud om innleggelse.}

(3) defineres det fem sentrale mål i utviklingen av tjenestetilbudet: 1 . Bedre tilgjengelighet og lik tilgang uavhengig av bosted, 2. Bedret kvalitet og lik behandling uavhengig av bosted, 3. Bedret samhandling og kontinuitet i akuttjenestene, 4. Bedre ressursutnyttelse og 5. Brukervennlige tjenester ved geografisk nærhet og brukerinvolvering i egen behandling.

\section{HENSIKT}

Erfaringskonferanser i 2008 og 2009 , for de den gang etablerte ambulante akutteamene, dokumenterte at det var usikkerhet både $\mathrm{i}$ forhold til hva som var god praksis innen fagområdet og til antallet team som faktisk var etablert. Konferansene viste stor variasjon når det gjaldt faglig profil og arbeidsmåter knyttet til tilgjengelighet, bemanning, arbeidsoppgaver, åpningstider, samarbeid med kommunehelse- blert ved distriktspsykiatriske sentre i Norge. Informasjonen som ble etterspurt er knyttet til følgende områder; hvorvidt det er etablert ambulant akutteam eller ikke, gjeldende opptaksområder, teamets åpningstider, aktuelle bakvaktordninger, hvor fagpersonene vanligvis møter brukere, tilgjengelighet til krisesenger, samarbeid med pårørende og henvisningsrutiner. Der det er opprettet team ble dato for dette etterspurt. Videre er tidspunkt for planlagt opprettelse av ambulant akutteam dokumentert der dette foreligger.

\section{Metode}

Studien ble utført ved telefonintervju til samtlige distriktspsykiatriske sentre i Norge. Telefonintervju ble valgt som metode for å gjennomføre kartleggingsundersøkelsen raskt, sammen med ønsket om

\section{Pasienters pårorende skal i så stor grad som mulig inviteres inn $i$ behandlingssamarbeidet.}

tjenesten og disponering av krisesenger. Hensikten med denne studien er å kartlegge og systematisere kunnskap om etable- en høy svarprosent. Et strukturert spørreskjema med seks lukkede hovedspørsmål ligger til grunn for studien. Datainn- samlingen forgikk i uke 4 (25. -29 . januar) i 2010 og syv forskere var knyttet til prosjektet «Krisehåndtering og hjemmebehandling i lokalbasert psykisk helsearbeid». En felles prosedyre for telefonintervjuet var utarbeidet. Informantene var enten teamleder, fagperson, eller merkantilt ansatt i teamet eller ved det distriktspsykiatriske senteret. Svarprosenten var 100 prosent. Tre resultatområder ble identifisert: tilgjengelighet av ambulante akuttjenester, forekomst og bruk av krisesenger og muligheter for ambulant arbeid, og mobilisering av familie- og nettverk.

\section{RESULTATER}

I 2006 var det 76 distriktspsykiatriske sentre i landet (11), og i 2010 har dette tallet økt til 79. Ved gjennomføring av telefonstudien er det totalt 79 distriktspsykiatriske sentre som kunne ha opprettet ambulant akutteam. Telefonintervjuene viser at tre distriktspsykiatriske sentre har samordnet organiseringen av ambulant akutteam med et annet distriktspsykiatrisk senter. Dette medfører at det totale antallet informanter i denne undersøkelsen er 76. Det totale antallet distriktspsykiatriske sentre som har opprettet ambulant akutteam er 51, mens 25 ikke har opprettet team enda $(\mathrm{N}=51)$. Av de 25 som ikke har opprettet team, er det seks distriktspsykiatriske sentre som planlegger oppstart av ambulant akutteam i løpet av 2010.

\section{Tilgjengelighet}

I denne studien omhandler tilgjengelighet både tidspunkt på døgnet teamet kan kontaktes og hvem som kan kontakte det. Undersøkelsen skiller mellom åpningstider på hverdager og 
i helg og høytider. Alle de 51 teamene har åpent på dagtid hverdager. Av disse er det 21 team som i tillegg har åpent på kveld hverdager. Videre har ett av teamene tilbud om natten, altså «24/7» slik anbefalingen fra Sosial- og helsedirektoratet tilsier (3). Når det gjelder åpningstider $\mathrm{i}$ helg og høytider svarer 21 team at de har åpent i helger og høytider, mens 30 opplyser at de ikke har det. Det samlede bildet av åpningstider viser at tre team har åpent på dagtid hele uken, altså inklusive helg og høytider. 27 team har åpent på dagtid men ikke i helg og høytider. 17 team opplyser at de har åpent dag og kveld på hverdager og i helg og høytider. Tre team har åpent dag og kveld på hverdager, men ikke i helg og høytider. Ett team har åpent 24 timer i døgnet både hverdag, helg og høytider. Hovedvekten i materialet ligger på team som har åpent dag og kveld på hverdager, men ikke i helg og høytider (27) og team som har åpent dag og kveld både hverdag, helg og høytider (17). Samlet utgjør disse to gruppene 44 team. På spørsmål om de har en bakvaktsordning når teamet ikke er tilgjengelig svarer 31 team at det har de, mens 20 team ikke har det.

Henvisning til ambulant akutteam kan enten gjøres ved direkte henvisning eller ved henvisning fra offentlig instans. Direkte henvisning innebærer i denne sammenheng at enhver kan kontakte teamet ved bekymring. Dersom det skulle vise seg å være behov for det, så innhentes henvisning fra offentlig instans i etterkant. Henvendelsen kan da komme fra bruker, pårørende eller andre instanser. I alt 34 team tar imot direkte henvisninger, mens 17 team krever henvisning fra offentlig instans. Det som refereres til som offentlig instans kan da være fastlege, legevakt eller annen psykisk helsetjeneste.

\section{Krisesenger}

En del av teamene disponerer på ulike måter krisesenger. Krisesenger representerer forskjellige former for tilbud om innleggelse. Det kan handle om krisesenger $\mathrm{i}$ en post ved det distriktspsykiatriske senteret, som bare teamet disponerer til innleggelser for pasienter de vurderer har behov for døgntilbud. Det vil si at sengene ikke benyttes dersom teamet ikke har behov for dem. Andre steder kan teamet ha avtale med en post om at brukere som er til behandling hos teamet, skal

\section{Ambulant nettverksorientering}

To sentrale helsepolitiske føringer for de ambulante akutteamene er at de skal arbeide nettverksorientert og ambulant (3). Det å jobbe nettverksorientert innebærer at pasienters pårørende $\mathrm{i}$ så stor grad som mulig skal inviteres inn i behandlingssamarbeidet. Samarbeidet med pårørende blir kartlagt ved spørsmål om teamet ofte samarbeider med pårørende, og om hvorvidt pårørende var med i siste samtale. Her svarer 38 team at de samarbeider hyppig med pårørende, 11 team svarer at de av og til samarbeider med pårørende, mens to team svarer at de sjelden gjør det. På oppfølgingsspørsmål om hvorvidt pårørende var til stede $\mathrm{i}$ siste

\section{Det at teamet skal arbeide ambulant inne- bærer at de skal reise hjem til pasienten.}

prioriteres og legges raskt inn på posten dersom teamet ber om det. Av teamene er det 33 team som oppgir å disponere krisesenger, mens 18 team ikke disponerer slike. Antall krisesenger som disponeres ligger mellom en og åtte. I det samlede materialet er det ni team som disponerer to senger hver, og to team disponerer syv og åtte senger. Antallet varierer sterkt. Gjennomsnittlig disponerer teamene tre krisesenger hver. Hovedvekten av teamene, 21 stykker, disponerer mellom en og fire krisesenger hver. Et av spørsmålene omhandler hvor ofte teamet bruker krisesengene de disponerer. 12 team oppgir at krisesengene brukes daglig, ti oppgir at de brukes ukentlig, ti svarer månedlig og ett team svarer ikke på dette spørsmålet. samtale er det 23 team som svarer ja og 28 team som svarer nei.

Det at teamet skal arbeide ambulant innebærer at de skal reise hjem til pasienten og møte ham eller henne på vedkommendes hjemmearena. Erfaringskonferansene for de ambulante akutteamene i 2008 og 2009 har vist at dette praktiseres svært ulikt. Enkelte team har en faglig forståelse om at det er viktig å møte pasientene hjemme og har dette som sin vanlige behandlingsform. Andre team arbeider primært i teamets kontorer eller base. Det er betydelig variasjon i hvorvidt teamene i hovedsak giør sine vurderinger og ivaretar behandlingstilbudet på teamets base, hjemme hos pasienten eller andre steder som måtte egne seg. På spørsmål om hvor teamet møter pasienten hyp- 
pigst svarer 31 team hjemme hos pasienten og 20 team svarer på teamets base.

\section{DISKUSJON}

Ved inngangen til 2010 er det to tredjedeler av landets distriktspsykiatriske sentre som har opprettet ambulante akutteam. Stortinget vedtok i 2005 at det 76 slike team skulle vært etablert ved utgangen av 2008.

implementering og utvikling av teamene. Det er med rette blitt etterspurt forskning og vitenskapelig dokumentasjon av effekten av ambulante akuttjenester. Både i hvilken grad teamenes arbeidsformer har medvirket til å redusere innleggelser i sykehus, og bedret kvaliteten ved ambulante akuttjenester for pasientene $(1,2,12)$. Noen internasjonale

\section{Studien viser at de fleste teamene kun arbeider på dagtid.}

Ved undersøkelsestidspunktet er det er fortsatt 25 distriktspsykiatriske sentre som har valgt ikke å etablere slike team. Det er noen forhold vi mener det er viktig å drøfte i tilknytning til dette. For det første ønsker vi å peke på noen sammenhenger som kan forklare variasjonen i opprettelse av ambulante akutteam i Norge. For det andre er det interessant å diskutere om teamenes arbeidsform faktisk bidrar til økt tilgjengelighet for pasientene slik intensjonen med ambulante akutteam ble beskrevet. For det tredje mener vi det har betydning å reflektere over hvordan ønsket om utvidede ambulante tjeneste og større involvering av pårørende, er ivaretatt.

Vedrørende variasjonen i opprettelse av akutteam kan en mulig forklaring være Stortingsvedtakets mangelfulle begrunnelse og forankring i faglig og studier peker særlig på det forhold at teamenes gatekeepingfunksjon er avgjørende når en skal evaluere en mulig reduksjon av innleggelser og bedret tjenestekvalitet $(13,14)$. Gatekeeping-funksjonen betyr at ingen pasienter får tilbud om innleggelse uten at de har vært vurdert av et ambulant akutteam. Modeller som innebærer en vei inn til akuttjenester er svært avgjørende i forhold til bruken av innleggelser og ønsket om reduksjon av disse $(13,14)$.

Funnene i vår studie kaster også lys over en vesentlig side hva utvikling og implementering av nye tjenestetilbud i praksis angår. Det kan være grunn til å spørre seg om «bottom-up» eller «top-down» er den mest egnede strategi for tjenesteutvikling og endringsprosesser. Er tjenesteutviklingens vilkår best ivaretatt gjennom vedtak i

\section{Det er stor variasjon i de etablerte teamenes profil og arbeidsmåter.}

vitenskapelig kunnskapsstatus. Denne mangelfullheten kan ha bidratt til både faglig skepsis og motstand når det gjelder
Stortinget som skal være direkte styrende for praksis? I hvilken grad er det viktig å undersøke og belyse hvorvidt det kliniske felt føler seg forpliktet til å virkeliggjøre demokratrisk fattede vedtak? Undersøkelsens resultat viser at en tredjedel av landets distriktspsykiatriske sentre fortsatt ikke har etterfulgt Stortingsvedtaket om etablering av ambulante akutteam. Dette kan betraktes som uttrykk for et demokratisk underskudd i psykisk helsefeltet - at et Stortingsvedtak nødvendigvis ikke trenger å bli etterfulgt. På den annen side kan de distriktspsykiatriske sentres valg forstås som en rettmessig faglig skepsis mot å implementere et nytt tjenestetilbud som savner vitenskapelig begrunnelse. Det har ved flere anledninger blitt reist spørsmål ved hvorvidt de ambulante akutteamene kan forsvares faglig i forhold til de oppgaver de skal løse ved å møte personer i psykisk krise $(1,2,12)$. Ved å legge en systematisk vitenskapelig kunnskapssammenstilling til grunn for innføring av ambulante akutteam, kunne man muligens sikret større tillit til implementering av de samme teamene. På den måten kunne man oppnådd større lojalitet til det demokratisk fattede vedtak.

En sentral målsetting med ambulante akutteam er økt tilgjengelighet av tjenester for innbyggere som opplever psykiske kriser. Det har også vært understreket ivaretakelse av likeverdig behandling av samme tilstand uavhengig av bosted $\mathrm{i}$ landet. Studien viser at de fleste teamene kun arbeider på dagtid. Noen få har utvidet åpningstid til kveld og i helger. Bare ett team har døgnåpent alle dager i uken. Siden ordningen med ambulante akutteam i stor grad er inspirert fra Storbritannia og Finland, er det interessant å sammenligne med noen forhold 
ved deres praksis. I begge land er det vektlagt en tilgjengelighet på 24 timer i døgnet hele uken $(13,14)$. Et grunnleggende prinsipp er døgnåpne tilbud og gate-keepingfunskjonen som beskrevet over. Vår studie viser at godt over halvparten av teamene (31) har bakvaktsordning utenom åpningstid. Når det gjelder hvor hjelpen gis, er det 31 team som fremholder at de primært treffer brukere hjemme. Internasjonale studier $(6,13,14)$ viser at den primære samarbeidsarena er brukerens hjem, og at hjemmebehandling er et sentralt begrep i akuttbehandling. Våre funn kan bidra til en diskusjon om hvorvidt den norske utgaven av ambulante akutteam faktisk bidrar til økt tilgjengelighet og lik tilgang til tjenester uavhengig av bosted. Så langt kan det synes som at teamene gir en økt tilgjengelighet i tjenestetilbudet primært på dagtid, og at tilbudet på kveld og $\mathrm{i}$ helger variere med det respektive distriktspsykiatriske senterets akutte tjenestetilbud. Funnene viser også stor variasjon i hvorvidt begrepet ambulant innebærer at teamet drar hjem til personer i krise eller om det er personen(e) som kommer til teamet. Et interessant aspekt ved funnene er også hvem det er som fastsetter hvor man skal møtes. Målsettingen om økt tilgjengelighet for en person i krise, kan innebære at vedkommende ikke er i stand til å reise noe sted eller vil ha det best med å få hjelp hjemme. Retten til medbestemmelse $i$ valg av sted og tidspunkt for møtet med teamet kan ha stor betydning for krisehåndteringen. Et annet område der studien synliggjør fleksibilitet i tilgjengelighet, er at hovedtyngden av teamene tar i mot henvendelser uten krav om henvisning fra fastlege, legevakt eller andre kommunale helsetjenester.

Det tredje området vi er opptatt av er hvordan intensjonene om mer ambulant tjeneste og større involvering av familie og nettverk er ivaretatt. Studien viser at to tredjedeler av teamene samarbeider hyppig med pårørende. Funnene er viktige etter som en sentral målsetting med de ambulante akutteamene er å arbeide $\mathrm{i}$ et familie- og nettverksperspektiv $(3,5,6)$. Siktemålet er både øt tilgjengelighet og metodisk fleksibilitet, men også ønsket teamenes profil og arbeidsmåter. Det bør vurderes hvorvidt man skal utvikle retningslinjer for «Best practice» for tjenestetilbudet i teamene eller om man skal akseptere forskjellene og tenke på det som en styrke gjennom kontekstuell tillemping. Videre ser vi stort behov for styrking av forskning innen de ambulante akutteams fagprofiler og arbeidsmåter med særlig vekt på komparative studier knyttet til målsettingene med tjenestetilbudet. En slik forskningstilnærming bør sees i lys av internasjonale studier og forskning, og man bør involvere

\section{En sentral målsetting med ambulante akutt- team er okt tilgjengelighet av tjenester for innbyggere som opplever psykiske kriser.}

om økt bruker- og pårørendemedvirkning i behandlingssamarbeidet. Kombinasjonen av å møte familien i hjemmet og økt brukerinvolvering sikter mot en samarbeidsarena karakterisert av trygghet, forutsigbarhet og en optimalisert dialog $(5,6)$. Slik kan samarbeidet bidra til å fremme mobiliseringen av ressurser hos personen i krise og nettverket hvor målet er å kunne mestre den aktuelle krisesituasjonen sammen med teamet. Et annet spørsmål er selvsagt om pasienter og pårørende selv i de kliniske situasjoner opplever at de blir sett og hørt og har reell mulighet til medbestemmelse i behandlingsplanlegging.

\section{KONKLUSJON}

Studien viser at det er betydelige forskjeller på hvorvidt de distriktspsykiatriske sentrene har etablert ambulante akutteam for personer over 18 år. Det er også stor variasjon i de etablerte klinikere, brukere og pårørende i forskningsutformingen.

Stian Biong, Marthe Eklund, Reidun Stenersen og Monika Gullslett har alle bidratt i design- og datautviklingen av studien.

Denne artikkelen er et resultat av forskningsprosjektet Krisehåndtering og hjemmebehandling i lokalbasert psykisk helsearbeid (KHHB). Prosjektleder er professor Suzie Kim og professorene Marit Borg og Bengt Karlsson er forskningsledere. Prosjektet er finansiert av Norges forskningsråd i perioden 2007 til 2011. Vi takker ansatte i Vestre Viken HF, Klinikk for psykisk helse og rus, medlemmer av Mental Helse Buskerud og medlemmer av Landsforening for pårørende innen psykiatri i Buskerud for deres deltakelse i og ulike bidrag til forskningsprosjektet. 


\section{REFERANSER}

1. Bergerud T, Møller P, Larsen F, Veenstra M, Ruud T. Krisepost ved distriktspsykiatrisk senter reduserer ikke akuttinnleggelser i sykehus. Tidsskr Nor Lægeforen 2009; 129: 1973-6.

2. Kolbjørnsrud 0, Larsen F, Elbert G, Ruud T. Kan psykiatrisk akutteam redusere bruk av akuttplasser ved sykehus? Tidsskr Nor Lægeforen 2009; 129: 1991-4.

3. Sosial- og helsedirektoratet. «Du er kommet til rett sted ...». Ambulante akuttjenester ved distriktspsykiatriske sentre. Rapport 03/2006, IS-1358, Oslo, 2006.

4. Ot.prp. nr. 1. (2004-2005). Statsbudsjettet for budsjettåret 2005

5. Karlsson B, Borg M, Kim HS. From good intentions to real life: introducing crisis resolution teams in Norway. Nursing Inquri 2008;15(3): 206-215.
6. Johnson S, Needle J, Bindman, JP, Thornicroft G. Crisis resolution and home treatment in mental health. University Press, London; Cambridge. 2008.

7. Det Kongelige Sosial- og helsedepartement. Om opptrappingsplan for psykisk helse 1999-2006. Endringer i statsbudsjettet for 1998. St prp nr 63 (1997-98). 1998

8. Fretheim A. Flere og bedre evalueringer av helsetjenesten. Tidsskr Nor Lægeforen 2009: 129: 1972

9. Pettersen B, Johnsen R. Legers oppfatning av samhandling mellom nivåene i helsetjenesten. Tidsskr Nor Lægeforen 2007: 127: 565-8.

10. Wenstøp, F. Statistikk og dataanalyse. Universitetsforlaget, Oslo. 2002. 11. Sosial- og helsedirektoratet. DPS i Norge. Psykisk Magasin; november 2006.
12. Glover G, Arts A, \& Babu KS. Crisis resolution/home treatment teams and psychiatric admission rates in England. British Journal of Psychiatry 2006; 189 . 441-445.

13. Johnson S. Crisis resolution and intensive home treatment teams. Psychiatry $2007 ; 6: 8,339-342$.

14. Seikkula, J, Aaltonen, J, Alakare, B, Haarankangas, K, Keränen, J. \& Lethinen, V. Five-year experience of first-episode nonaffective psychosis in open-dialogue approach: Treatment principles, follow-up outcomes and two case studies. Psychotherapy Research 2006; 16 (2), 214-228

Les kommentaren på side 69 >>

\section{Les flere anmeldelser på nett}

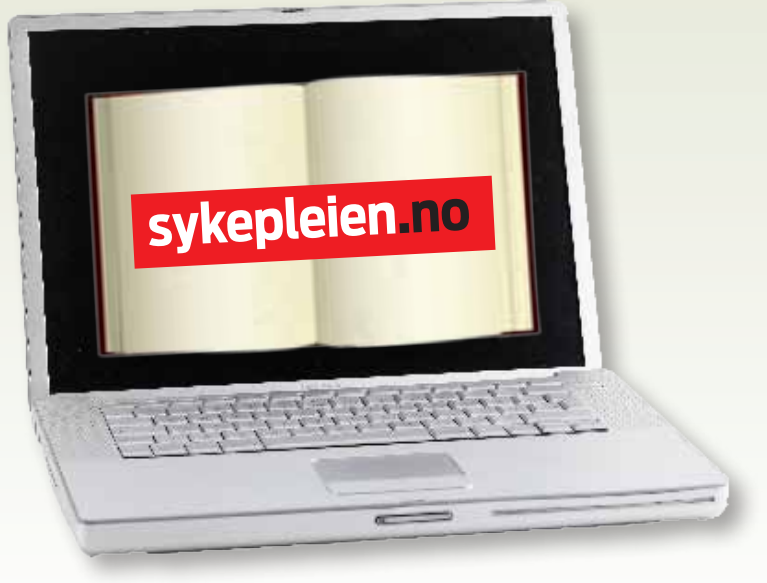

- Alle bokanmeldelser i Sykepleien legges også ut på nett.

- Let og les i vårt bokarkiv på www.sykepleien.no

- Anmeldelsene ligger under menyknappen «fagutvikling» $\emptyset$ verst til venstre på siden.

- Sykepleien anmelder mest fagbøker innenfor sykepleie, medisin og samfunnsfag, men også noe skjønnlitteratur. 